\title{
Study on the Failure of Connection in A Passage to India
}

\author{
Qiufang Dong \\ College of Liberal Arts \\ Jinan University \\ Department of English Teaching and Research \\ Guangdong AIB Polytechnic \\ Guangzhou, P.R. China
}

\begin{abstract}
A Passage to India poses the question whether it is possible for an Englishman and an Indian to be friends within the context of British colonialism. Forster uses this question as a framework to explore the general issue of Britain's political control over India on a personal level. He explores the issue of connection on the basis of three groups of people: the general Anglo-Saxon People in India, the proIndian British, and the Indian people. After analyzing the relations of these three groups of people, this paper concludes that it is mainly due to the colonist domination that distorts personal relations and leads to the final failure of connection.
\end{abstract}

Keywords-A Passage to India; E.M. Forster; failure of connection

\section{INTRODUCTION}

A Passage to India is regarded as one of the greatest novels in world literature. In this novel, E.M. Forster portrays a picture of the society in India under the British colonial domination. The story centers around four characters: an Indian doctor, Mr. Aziz, a British schoolmaster, Cyril Fielding, Mrs. Moore and Miss Adela Quested, two ladies who newly arrive in India for a visit. Dr. Aziz kindly invites Mrs. Moore and Miss Adela Quested to see a local tourist center-the Marabar Caves. During the trip, Adela falsely assumes Aziz for assaulting her. Aziz is brought to court and the trial arouses great tensions between the British and Indian. The whole story begins and ends with the question whether people of the two races can be truly connected.

Forster's own understanding of the theme of the novel differs from many critics'. Forster is a liberal and his political views are quite personal. In 1939 he published an essay entitled "What I believe" on the threshold of World War II. In it he stated that "tolerance, good temper and sympathy are what really matter." (Cavaliero 150) But even Forster himself could not deny the fact that he wrote this novel after the political event in 1919: the Amritsar Incident. Because of illegal gathering hundreds of Indian people were shot to death on the order of a British officer. Thus many contemporary reviewers take this novel as a political one and believe it to be a medication on the question whether the British should terminate its domination over India. And yet
Forster's A Passage to India is a great classic because it is primarily concerned not only with social or political problems, but with man and his relationship with the universe and the other humans. In searching for the connection with other people and the universe, the characters only find isolation, which results from many factors. Of all the factors, the British colonialism and racism take the leading role. It distorts the normal relations between people of the two races.

Forster mainly explores the issue of connection on the basis of three groups of people. The first is most of the English officials working in India, including Mr. Turton and Rony, who hold the strong belief that they are in India to be serving for the cause of Great Britain and doing good for the Indians. Another group includes Mrs. Moore, Fielding and Adela who try to interact with the locals on an equal footing and yet are doomed to fail. The last group is the Indians. They are the victims trapped in a miserable situation even though it is on their own homeland.

\section{ThE GENERAL ANGLO-SAXON PEOPLE IN INDIA}

Most of the Anglo-Saxon people in India are Europeancentered and consider themselves superior to the Indians. All the Indians are believed to be lazy, dirty, irresponsible and uncivilized subjects. They are the "other" who stands for everything opposite to the British. Arthur James Balfour once described the British colonist officials abroad to be "selfless administrators doing their work amidst tens of thousands of persons belonging to different creed, a different race, a different discipline and different conditions of life."(Said 34) That is the case of the officials working in India. They firmly believe that the Indians lack the ability to govern themselves. The British claim that the Indians are living a far civilized life under the British government. They are sacrificing themselves to stay in India to rule and to change. In one club gathering, when the amateur orchestra played the National Anthem, the conversation and billiards of the British stopped and the faces of those officials stiffened. The anthem of the Army of Occupation reminded every member of the club that he or she was British in exile. This produced some sentiment and useful accession of will power. For the newcomers who were not a member of this 
group like Mrs. Moore and Adela, this seemed so hard to understand. Deep in those officials' mind is what Edward W. Said refers to as the "orientalist" way of thinking. It is the "western style for dominating, restructuring, and having authority over the Orient."(Said 3) Before the colonists came to the oriental world, the Asian nations lived in an organized world of their national and cultural boundaries and had principles of internal coherence. But for the British colonists, the orient exists just to help them see how advanced and civilized the western world is.

With all the orientalist ideology, people of this group not only have no intention to connect with the Indians, but they try to prevent other British people from doing so. In a gathering, when Rony found that his mother was talking with some Indian people, he became nervous and warned her to keep distance because he regarded it a disgrace for the British to talk with locals. When Mrs. Moore criticized her son for not treating the Indian people fairly, he argued that he was in India to work and hold this wretched country by force. He claimed he was not a missionary or a Labor Member or a vague sentimental sympathetic literary man and he came to do something more important than to treat the locals decently. For his mother and Adela's opposition, he actually felt even wronged. For him, "every day he worked so hard in the court trying to dispense justice fearlessly, to protect the weak against the less weak, the incoherent against the plausible, surrounded by lies and flattery" (Forster 40) In Fielding's house, when he found Adela was chatting with Aziz and Godbole, the Indian, he got angry and refused to look at Aziz and ignored his attempt to chat with him. As for the trip to the Marabar Caves, it was only after he learned that Fielding would go together with the two ladies that he complied with the plan. When Adela claimed herself to be assaulted, he had no doubt that it must be true.

After the Marabar Incident, the Anglo-Indians rallied to Adela's case to show their support for her and openly voiced condemnation for the Indians. Even if Mr. Turton knew nothing of what happened, he firmly believed Aziz to be guilty. However, he also blamed on Adela, claiming that nothing but disaster would occur when Indians and English interacted socially. For the British, the trial gave them an opportunity to express their strong disgust towards the evil Indians. When Fielding chose to argue for Aziz, he was denounced by most of his countrymen.

Forster's portrayal of Anglo-India is fair. The insolence of British administrators like Turton and the behaviors of their wives are hard to bear for the Indians. These British rulers live in a narrow, circumstanced world of their own. In spite of the assumption of being the guardians of the Indian, they know little of them and have no intention of doing so. Thus it is impossible for them to connect with the Indian.

\section{THE PRO-INDIAN BRITISH}

Compared with most of the other British, Mrs. Moore, Fielding and Adela take a much more positive attitude towards the Indian. They seem to hold no prejudices against the Indian, and genuinely hope to make friends with them. But it is through their interactions with the Indian that
Forster proves how hard it is to attain a real connection even if both sides are good-willed.

It is through Mrs. Moore that Forster expresses his cosmic vision. He intends to advocate that universal love can transcend everything: politics, nationalities, religion, social ranks and age. Mrs. Moore believes that political and class divisions can only be bridged by the spirit of love. It is based on love that she can be a real friend of Aziz and sympathizes with him for his being mistreated by the British officials. Her respect for the local religion rituals wins Aziz's favor.

Mrs. Moore is portrayed as a loving and understanding Goddess-like figure in the novel. Unlike her son Rony, she finds little affinity with the British colony in Chandrapore, and she is bored by the social activities of the club. She tries to seek friendship with the local Indians, striking up a chord of sympathy with Aziz, the sensual Moslem doctor and Godbole, the mystical Hindu teacher. She discovers in the process that her traditional Christian upbringing no longer satisfy her and becomes increasingly interested in the mysticism of the orient.

But Mrs. Moore undergoes religious crisis as the story develops. When she first encountered Aziz in the mosque, she was a true Christian and firmly believed in God. But as she stayed longer, her loyalties to religion, race and family were undermined. Through Godbole's talk and song, she was attracted by the Hindu view of life. As a result of the echo in the caves, Christian doctrine with its great promise "Let there be light" seems no longer valid. She withdrew from both family and social responsibilities and became indifferent to the reconciliation between Rony and Adela. She refused to see Adela during her illness. Even if she was convinced of Aziz's innocence, she did not want to testify for him. She retreated into a cave of her own. On her departure from India back to Britain, she seemed entirely disillusioned and quickly died. Her death implies that her belief system collapses and she possibly realizes universal love is impossible to attain because humans can never truly understand each other.

Fielding is another positive character Forster depicts in this novel. He is the only one of the major characters who seems genuinely comfortable among both the British and the Indian. He seeks out people of intelligence and culture, whatever their race. As a British, he finds it pleasant to associate with educated members of the Indian community, like Hamidullah and Godbole. He is a shrewd judge of character. He trusts Aziz and when Aziz is wronged, he stands by him and works hard to help him out.

But even for Fielding, when he gets more closely involved with the Indian, he feels the great gulf between the two races. "At the moment when he was throwing in his lot with the Indians, he realized the profundity of the gulf that divided him from them. They always do something disappointing. Aziz had tried to run away from the police. Mohammed Latif had not checked the pilfering. And now Hamidullah---instead of raging and denouncing, he temporized. Are Indians cowards? No, but they are bad starters and occasionally jib.”(Forster 149) Fielding may not realize that he also holds prejudice towards the Indians. 
Psychologist Plotnik and Mollenauer refer to prejudice as "an unfair, biased, or intolerant attitude towards another group of people."(Samovar and Porter 247) Prejudices are the products of social construction and are acquired gradually in the social institution. For a British living temporarily in India, it is not unusual for him to hear negative opinions of the Indians on a daily basis. Little by little the prejudices of the local British officials have their effect on him and change him. When he goes back to Britain, he has already been surprised at his own heroism towards Aziz. He is not sure that if he were given another chance, whether he will defy his own people for the sake of an Indian.

Adela, as her family name suggests (Quested), is always trying to learn more about the Indian culture and its people. Before she came to India, she had been fantasying to see the "real India". After she landed in India, she could not wait to begin her journey to look for it through sightseeing and interactions with the Indians. Out of her request, Mr. Turton held the Bridge Party which turned out to be a total failure. She then went to a small gathering organized by Fielding to spend some time with the Indians, which was interrupted by Rony. After that, she accepted Aziz's invitation to see the Marabar Caves, and got the hallucination that she was assaulted by Aziz. Her various attempts to see a "real India" failed.

Adela's intention to see a "real India" and her hallucination in the cave actually reflect her orientalist expectation of India as an occidentalist. For many Europeans, the oriental is "less a place than a topos, a set of references, a congeries of characteristics, that seems to have its origin in a quotation, or a fragment of a text, or a citation from someone's work, or some bit of previous imaging, or an amalgam of all these."(Said 177) In India, she expected to see a land of romance with exotic scenes and beings. She is disappointed to find nothing of this sort when she is in India. It is hard for her to communicate effectively with the local. And as for the Marabar Caves which are supposed to be the representative of the exotic, she cannot find anything attractive. In hallucination, she recalled Mrs. Turton's words that the Indian male would take several wives so she directly asked Aziz how many wives he had got. This upset and annoyed Aziz and he left her alone in one cave and went to another to recover himself. Adela's false accusation reflects her being affected by the general Christian stereotyping of the Muslims. Gavin R. G. Hambly finds that "alleged Muslim sexual excess was a topic which had long been fascinated the clerical writers of medieval Europe, and it was one which over the centuries fueled the fires of prejudices."(Winks 37) According to Said, western writers and scholars create tons of works to highlight the libido of Muslims. People from the west are made to believe that the Muslim males are extremely lustful and have an obsessive preoccupation on sexuality. Adela might be wondering all these when she had the hallucination. Aziz is a victim of western orientalist institution and yet Adela is, too. Before and after the trial, Adela went through spiritual turmoil and her engagement with Rony was broken. She sadly went back to Britain.
Adela, Fielding and Mrs. Moore are the British who have been working hard to build connection with the Indians. But their failures prove that under colonist domination, with the cultural and political divisions, a real connection is out of the question.

\section{THE INDIAN PEOPLE}

For the Indians, even if they dislike the colonist domination, they hold a paradoxical attitude towards the British. On one hand, they wish to please the British and on the other hand, they despise themselves for behaving like this Aziz is a typical example. He loves his nation and is willing to do anything to fight for its independence. And yet when he is with the British, he tries every means to satisfy their needs. Unfortunately, his good intentions are constantly neglected and wronged. After his arrest and trial, he develops strong anti-British sentiments.

Aziz shows his paradoxical attitudes when he is with the British people. At the beginning of the story, when he was mistreated by his British superior and greatly outraged, he went to a mosque and met Mrs. Moore there. She listened to his story with sympathy. He was grateful to her and even flattered because few British treated the Indians so nicely. To impress his newly acquainted British friends, he volunteered to arrange a tour to the Marabar Caves. The two ladies were not so much interested and yet he took it as an opportunity to show his courtesy to the British. He made a great fuss of it as to borrow a whole set of western cutlery, prepare drinks and even arrange an elephant for the ladies to ride. He intended well and yet the trip ended tragically.

Forster portrays vividly how the Indian people are discriminated in their own land. They are banned from ruling their own country and kicked out of the so-called high-class social gatherings. Most of the Indian people live a miserable life and yet the British occupy the best residents. In the climax of the novel, when Adela accused Aziz for insulting her, Aziz was arrested and put into prison. His friends believed his innocence and yet almost all the British were convinced of Aziz's guilt. Adela's lawyer even remarked that the darker races are always physically attracted by the fairer, but not vice versa. The nonsense irritated the Indian. The trial brought a big political riot in town. Whenever the British were out on the street, they would be attacked by the Indian. Even if finally Adela accepted her mistake, the consequences of the incident were so great that people of the two races found it hard to co-exist on the same land any more.

\section{CONCLUSION}

The title of A Passage to India is borrowed by E.M. Forster from Whitman's poem "Passage to India". In the poem, Whitman praises that the successful building of Suez Canal improves the communication and travel between East and West, thus making a shorter passage to India possible. But Forster is far less positive. The novel can be considered as a kind of reflection of a liberal-minded and honest English writer. He questions if it is possible for the British and the 
Indians to set up a real connection and the answer is negative under British colonist domination.

It is impossible for the British to avoid the orientalist way of thinking and get out of the corporate institution that the British are staying in India to help and conquer the inferior. It is this way of thinking and ways of dealing with problems that lead to the final failure of the connection. In the contemporary world, globalization has changed the world to a small global village. People either from the "oriental" or from the "occident" are brought together far more than before. The failure of the connection in the novel enlightens us that we shall be careful of the hidden grip of ideological and cultural and political factors that will undoubtedly influence the way we perceive and interact with the world. Only by doing so can a real connection is possibly built between different races.

\section{REFERENCES}

[1] Cavaliero, Glen. A Reading of E.M. Forster. London: Macmillan Press, 1979.

[2] Said, Edward W. Orientalism. London: Penguin Group, 2003.

[3] Forster, E.M. A Passage to India. London: Aldine House, 1980.

[4] Winks, Robin W. Asia in Western Fiction. Manchester: Manchester University Press, 1990.

[5] Samovar, Larry A., and Richard E. Porter. Communication Between Cultures. Beijing: Beijing Foreign Language Teaching and Research Press, 2000. 